\title{
Portugal: Intertidal Archaeology and Submerged Coastal Landscapes
}

\author{
Nuno Bicho, Leandro Infantini, and João Marreiros
}

\begin{abstract}
People have lived along the Portuguese coast at least since Marine Isotope Stage (MIS) 5, over 100,000 years ago. While there are many known sites and archaeological evidence of human settlement on land, there are only a handful of known submerged or nearsubmerged locations, and these are all in the present-day intertidal zone. Throughout the period, diet was based on both terrestrial and marine mammals as well as fish and shellfish. This dietary regime was already in existence when Neanderthals populated the region. It appears that marine foods started to be used more frequently when the first anatomically modern humans arrived, some 33,000 years ago. Among the Mesolithic people who lived along the estuaries of the major rivers, marine food frequently composed c. $50 \%$ of the diet. With the introduction of agriculture, coastal resources became less important, although some submerged sites of Neolithic date testify to habitation directly at the seashore. Despite the current absence of known underwater prehistoric sites, apart from those in the intertidal zone, recent studies of offshore topography have identified a number of areas with good potential for archaeological prospection,
\end{abstract}

N. Bicho $(\bowtie) \cdot$ L. Infantini $\cdot$ J. Marreiros ICArEHB, Universidade do Algarve, Faro, Portugal e-mail: nbicho@ualg.pt; jmmarreiros@ualg.pt including cliff lines with underwater caves and drowned river valleys.

\section{Keywords}

Submerged $\cdot$ Underwater $\cdot$ Muge $\cdot$ Shell middens $\cdot$ Mesolithic $\cdot$ Palaeolithic $\cdot$ Neolithic

\subsection{Introduction}

Portugal is a small country on the southwestern limit of the European continent. With an area slightly over $92,250 \mathrm{~km}^{2}$, it has a coastline that exceeds $1000 \mathrm{~km}$ in extension. The long stretches of ocean-exposed beaches are intersected by several major estuaries, as well as extensive coastal lagoons bordered by barrier islands. While there are many important rivers that reach the Atlantic coast, namely, the Douro, with its mouth in the city of Porto, or the Guadiana that constitutes the border between Portugal and Spain in the south, there are two very large estuaries, the Tagus and the Sado, forming large bodies of water many square kilometres in area, with depths from 40 to $60 \mathrm{~m}$ and $>100 \mathrm{~km}$ in length. In addition, the Portuguese coast has two important barrier-island complexes, the Ria de Aveiro and Ria de Formosa in Faro, respectively, 45 and $60 \mathrm{~km}$ long. The continental shelf exposed during periods of lowest sea level is relatively narrow-c. 20-50 km wide-with several deep canyons rep- 
resenting ancient river channels that would have brought the coastline of the Last Glacial Maximum to within a kilometre or two of the modern coastline (Fig. 14.1; Moura et al. 2017).

Today, during the summer months mostly around the southern coast, there is a very important upwelling system (Fiuza 1983; Loureiro et al. 2005). This system has produced a highly rich and diverse biomass that has strongly moulded the modern marine and coastal resources of the Portuguese economy, including the highly productive fish and shellfish industries. The

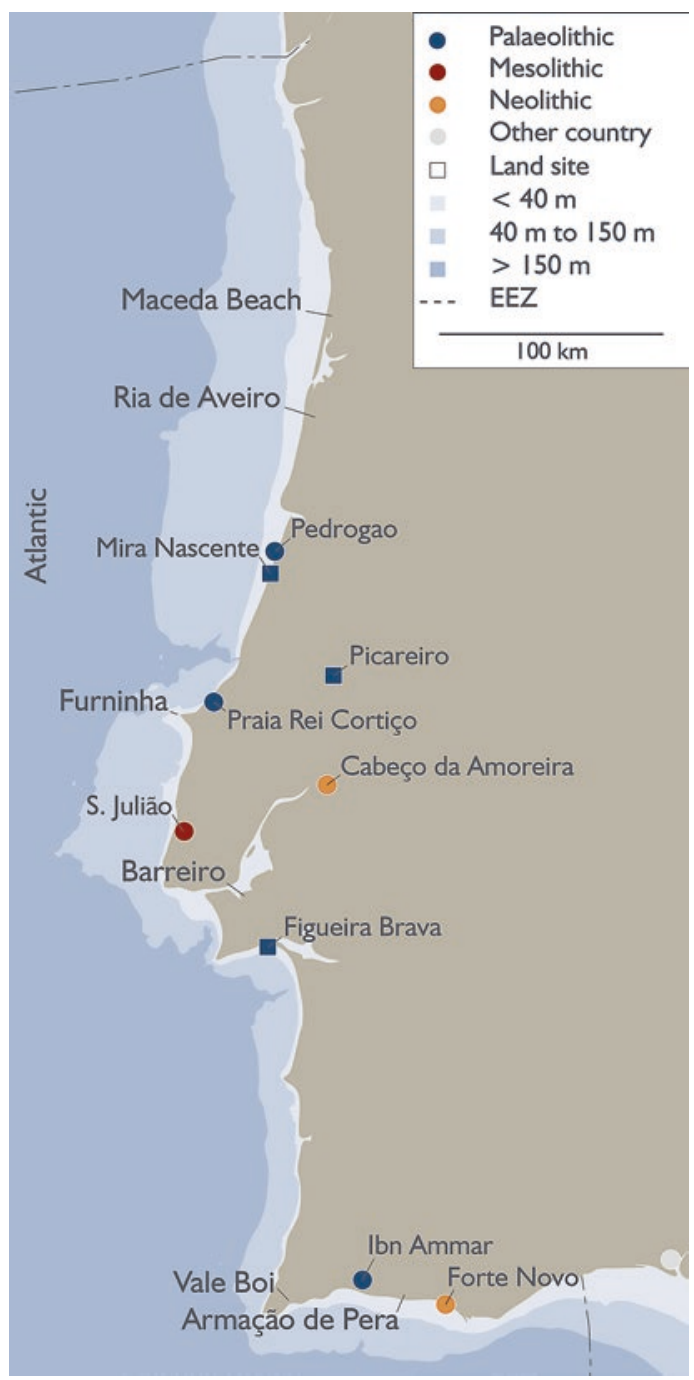

Fig. 14.1 Map of Portugal showing distribution of sites. Site information from the SPLASHCOS Viewer http:// splashcos-viewer.eu. Drawing by Moritz Mennenga
Portuguese upwelling, strong though it is today, was three to seven times higher during the last 100,000 years of the Pleistocene (Abrantes 1990, 2000), making the Atlantic coast an extremely rich and abundant food resource. Archaeological evidence, examples of which are presented below, testifies that the rich marine fauna was frequently exploited by humans from the Middle Palaeolithic period onwards and was likely fundamental for the development of the first human societies in SW Europe (Bicho and Haws 2008).

At present, we have identified only six prehistoric underwater sites - these include fully submerged as well as intertidal locations; three are dated to the Middle Palaeolithic, one to the Mesolithic and two to Neolithic occurrences. These sites were originally open-air locations, and those found in the intertidal zone are especially liable to destruction by wave action. Four have been partially excavated, and three are still part of ongoing projects in central and southern Portugal.

\subsection{Research History and Archaeological Context}

In 1879, Nery Delgado, a member of the National Portuguese Geologic Commission, excavated the cave site of Furninha (Fig. 14.1), located on the Atlantic limestone cliff on the Peniche Peninsula in central Portugal (Bicho and Cardoso 2010). The cave entrance located some $5 \mathrm{~m}$ above the modern sea level, with a 9-m-thick sequence, gave one of the earliest Portuguese examples of marine resource exploitation during the Middle and Upper Palaeolithic (Delgado 1884). Since then, other sites located usually within a few metres of the modern sea level have been found and have been excavated along the Portuguese Atlantic coast. Probably the most notable case is the cave of Figueira Brava (Antunes 2000a, 2000b), a Mousterian site some $30 \mathrm{~km}$ south of the Tagus estuary where remains of marine species such as dolphin and penguin were found as part of the diet. The cave entrance is just a few metres above modern sea level and might have been opened during MIS 5e. 
This trend of a component of marine and aquatic resources as part of the human diet is also present in many other sites, some further from the coast. This is the case at Vale Boi (Bicho 2004; Bicho and Haws 2008; Bicho 2015) in Algarve near the Cape of St. Vincent, with collection of shellfish, among other marine resources, starting at least some 33,000 years ago, and the cave of Picareiro (Bicho and Haws 2008), an inland site some $70 \mathrm{~km}$ north of Lisbon with coastal fish and shellfish remains starting during the Gravettian 28,000 years ago. These include clupeidae species (possibly shad or sardine) as well as cockles, clams and mussels (Bicho et al. 2003). In addition, proxy evidence is present at the Middle Palaeolithic site of Mira Nascente, near Nazaré (Benedetti et al. 2009; Haws et al. 2011). This open-air site in a coastal sand dune is dated to $\mathrm{c}$. 40 to 42,000 cal BP. Sedimentology indicates that the site was located on the edge of a lake very close to the shoreline. Use-wear analysis suggests that the extremely well-preserved flint assemblage was likely used for fish processing (Haws et al. 2011).

During the Last Glacial Maximum, c. 25,00020,000 cal BP, sea level was as much as c. $130 \mathrm{~m}$ lower than today (Lambeck et al. 2014), and the habitable land extended as much as $10-50 \mathrm{~km}$ out from the modern coastline. No trace of Palaeolithic habitation in this deeply drowned landscape is currently available. There are, most likely, two main reasons for this: the lack of systematic surveys and a generally highly erosive coastline due to the combined effect of waves, currents and tides.

Another relevant element in the history of coastal archaeological research in Portugal is the Early and Middle Holocene timeframe. During the Early Holocene, the Portuguese coast south of the Nazaré canyon was the location for a large number of coastal Epipalaeolithic and Mesolithic sites both in Portuguese Estremadura (Sousa 2004; Araújo 2009, 2012; Bicho et al. 2010; Araújo et al. 2014; Sousa and Soares 2016) and southern Portugal (Carvalho 2008; Valente 2008; Bicho 2009). Estuarine Mesolithic shell middens have been known since 1863 in the Muge area in the Tagus valley, some $60 \mathrm{~km}$ north-east of
Lisbon. The earliest occupations are dated to before $6000 \mathrm{cal} \mathrm{BC}$ and are thought to be the consequence of major coastal changes (Bicho et al. 2010) linked to the changing coastal morphology, rapid sea-level rise and a dramatic drop in coastal marine biomass and the so-called $8.2 \mathrm{ka}$ cold event (c. 8200 cal BP or c. 6200 cal BC) (Von Grafenstein et al. 1998). These locations are represented by some of Europe's largest shell middens with layers of marine shells up to $5 \mathrm{~m}$ thick. These accumulated next to a contemporaneous inlet in Muge and in Sado around 8000 years ago (Umbelino 2006; Bicho et al. 2010; Peyroteo Stjerna 2016). Stable isotope measurements of bones of humans buried in the shell mounds (Fig. 14.2) suggest that ca. $25-70 \%$ of the protein diet of these individuals derived from seafood (e.g., Umbelino 2006; Bicho et al. 2010; Peyroteo Stjerna 2016).

The emergence of agricultural societies in central and southern Portugal, with a process of acculturation and genetic mixing of the local Mesolithic communities with new immigrants from the East, took place some 7500 years ago (Bicho et al. 2017). Neolithic people, marked by Cardial ceramics, arrived in the western Algarve and the Portuguese Estremadura from the Mediterranean by sea (Carvalho 2008).

\subsection{Sites}

The above cases can be used as proxies for the use and exploitation of coastal environments during the Palaeolithic and Mesolithic on the Portuguese Atlantic coast, but unfortunately, there are very few cases of underwater prehistoric occurrences. Despite its near-1000-km-long Atlantic coastline, with its estuarine and lagoon coastal settings, Portugal has only six underwater archaeological sites and two examples of submerged forests.

Praia Rei Cortiço (Fig. 14.3). This is a Middle Palaeolithic coastal site located near Peniche (Haws et al. 2011; Minckley et al. 2015), where pollen and sediment evidence indicate that the site was originally located in a coastal 


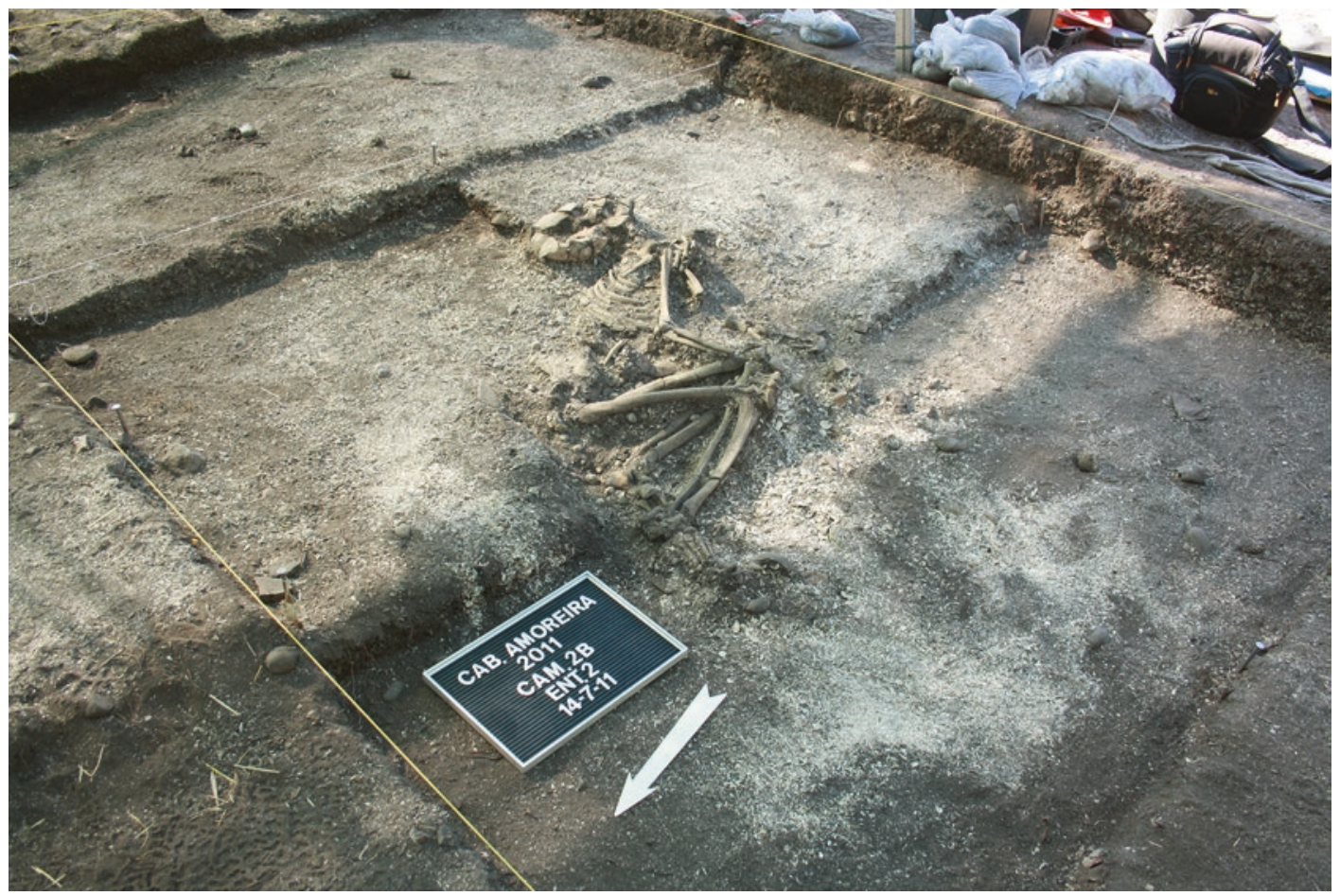

Fig. 14.2 Mesolithic human burial in Cabeço da Amoreira, Muge. The isotopic information indicates that this skeleton belongs to a person whose diet was composed of c. $50 \%$ marine resources. Photo by Nuno Bicho

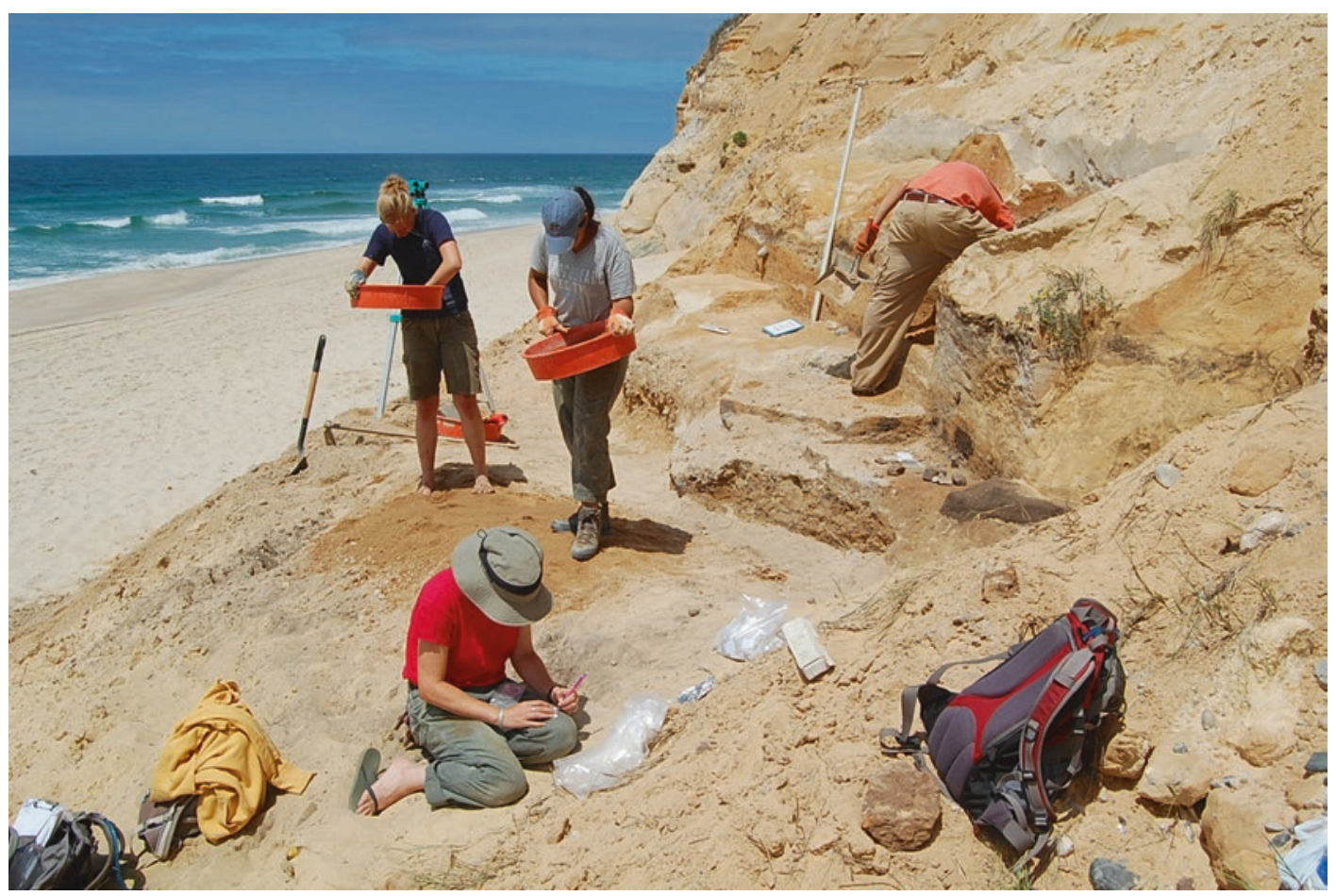

Fig. 14.3 Excavation at Praia Rei Cortiço during low tide. The archaeologists are standing just below the horizon that represents Neanderthal coastal occupation during the MIS 5 c. 115,000 years ago. Most of the site was washed away during a high tide in 2014. Photo by Jonathan Haws 
lagoon environment with a sea level similar to that of today (Minckley et al. 2015). Lithic artefacts are abundant and are typical of a Mousterian occupation. Cores follow a centripetal reduction sequence with common discoidal cores and very rare Levallois examples. Raw materials include quartzite, quartz and rare chert elements.

Praia do Pedrogão. This is also a Middle Palaeolithic coastal site (Aubry et al. 2005; Benedetti et al. 2009) located in the county of Leiria. The site is on the present shore, just on the higher section of the intertidal zone and, thus, during spring tides is subject to strong erosional forces. The lithic assemblage is composed of quartzite and quartz artefacts, with rare retouched stone tools. The technology is marked by the common presence of Levallois reduction sequences producing flakes.

Cabeço da Amoreira, in Muge. In 2011, a deposit was found below the modern local water table and associated with a prehistoric estuarine shoreline. The known sequence (testing has not yet reached the base of the cultural deposits) covers the period from at least Early Neolithic up to Iron Age horizons (Bicho et al. 2017) and is characterized by layers with very high organic content. The lithic assemblages are limited, while ceramics are very common, with some decorated examples.

The São Julião Mesolithic shell midden. Located north of Lisbon, near the city of Mafra, this is a shell midden complex, with at least four loci, of which at least one is within reach of wave action during very high spring tides in the estuary of the small Falcão River (Sousa 2004; Sousa et al. 2016). These shell middens have a limited number of very simple lithic assemblages, composed mostly of flakes. On the other hand, the sites have many hearths associated with diverse mollusc species including bivalves and gastropods.

The Middle Palaeolithic cave of Ibn Ammar. Located in the estuary of the Arade River (Fig. 14.4), near Portimão, this cave has many lower chambers that are inundated at high tide during spring tides, but the floor of the largest chamber is permanently underwater to a depth of at least $50 \mathrm{~cm}$. The human occupations (Mousterian, Early Neolithic and later) have been located only in the upper chambers, where it is possible to excavate (Bicho 2004; Carvalho 2008). The prehistoric artefacts found inside the cave include Mousterian centripetal discoidal cores and flakes made on quartz, quartzite and flint (Bicho 2004) and early Neolithic ceramics (Carvalho 2008).

The Neolithic site of Praia do Forte Novo. Located in coastal Algarve, this site was found during an extreme low water stand for a few days in 1999, and since then, it has been covered by sand and is usually underwater (Fig. 14.5) (Rocha 2003; Rocha and Barros 1999/2000). Thousands of pottery fragments have been recovered as well as hearths and features that may represent partly eroded remains of saltpans and huts.

Maceda beach submerged forest. Here, petrified macrofossil wood remains have been found near the city of Porto and dated to MIS 3-2 (Granja and Carvalho 1995; Granja et al. 2008).

Barreiro submerged forest. This is north of Lisbon and dated to the Early Holocene (García-Amorena et al. 2007).

All these sites are located within the intertidal zone, although the latter three are at the extreme lower limit and are exposed only in those rare moments of extremely low spring tides. Both Middle Palaeolithic sites, Praia Rei Cortiço and Praia do Pedrogão, are at the upper limit and are only reached infrequently by wave action.

\subsection{Prospects for Preservation and Discovery of Underwater Sites}

Until recently and following the idea of a major adaptation in late Pleistocene and Early Holocene times (Binford 1968; Flannery 1969), it was thought that marine resources were important in the economy and diet of the human populations 


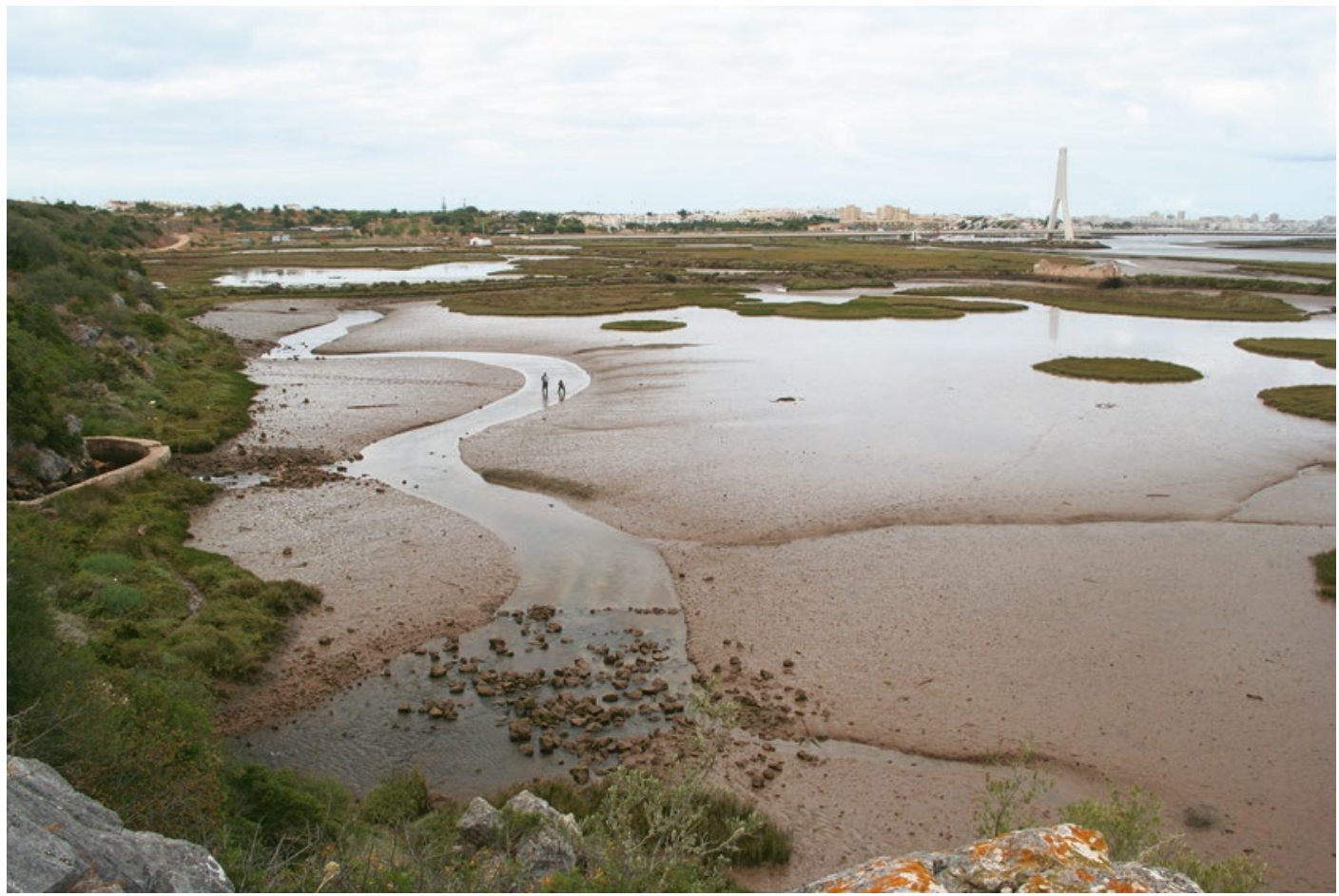

Fig. 14.4 View from Ibn Ammar entrance towards the estuary during low tide, when shellfish resources are available as well as fresh water coming out from the various cave springs (seen on the left side of the photo, where the wall is located). Photo by Nuno Bicho

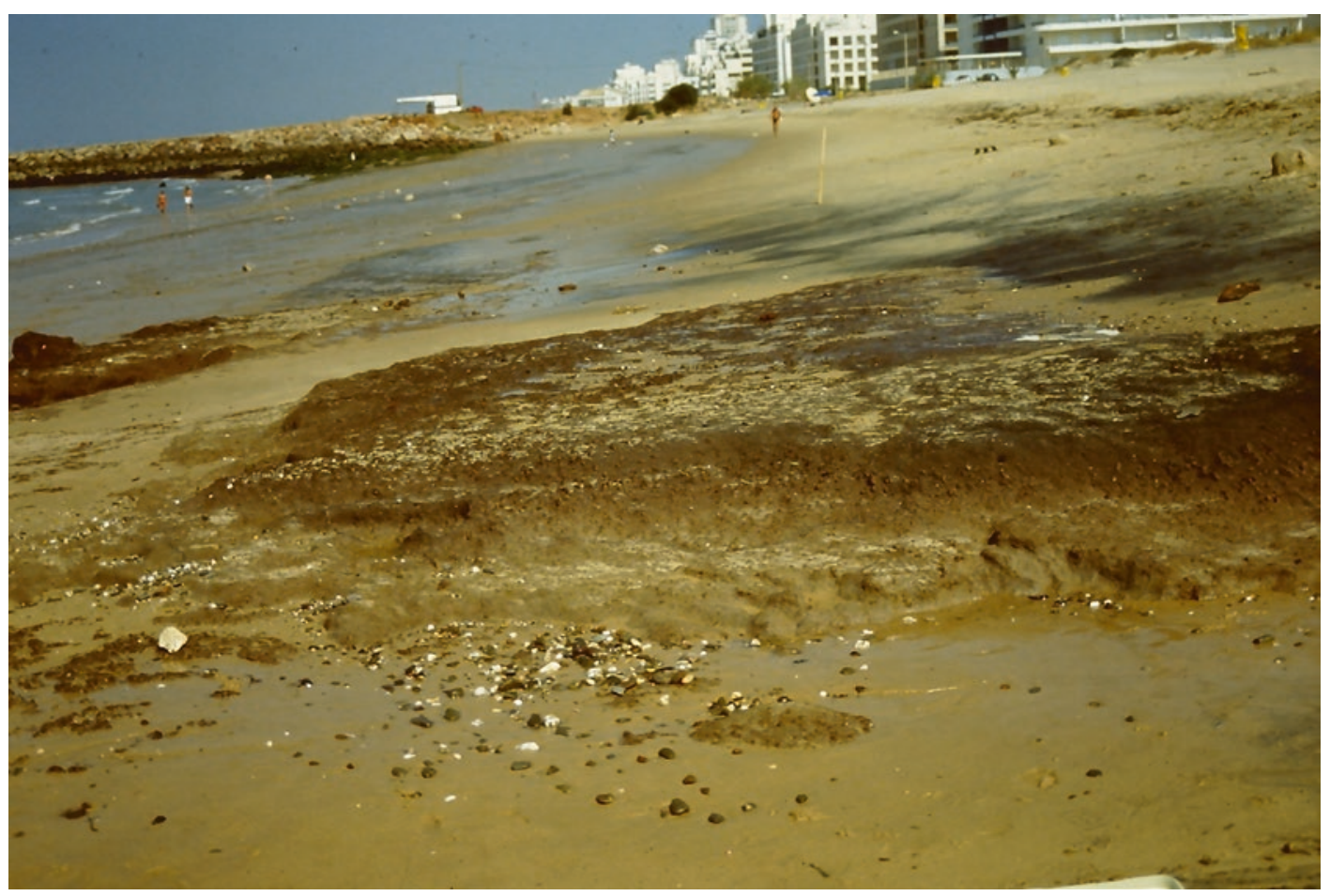

Fig. 14.5 The dark organic layer seen in the centre of the photo is rich in remains of coastal habitation. This c. 7000-year-old site, located in the intertidal zone, is shown here on a rare occasion of surface sand erosion due to wave and current action. Praia do Forte Novo. Photo by Leonor Rocha 
only from the Late Upper Palaeolithic onwards in Portugal. Data coming from different sites in central and southern Portugal, as well as a general change in paradigm in world archaeology (Erlandson 2001; Bailey and Milner 2002; Bailey 2004), have shifted the climate of opinion towards the view that marine resources and coastal adaptations were in use much earlier than previously thought (Bicho and Haws 2008). One of the key factors masking the archaeological evidence is the fact that many sites dating to the Palaeolithic and even to the Mesolithic are now submerged on the continental platform, down to $150 \mathrm{~m}$, due not only to general sea-level rise (Dias et al. 2000) but also to tectonic episodes during the last 120,000 years (Bicho and Haws 2008).

The submergence of sites as deep as $150 \mathrm{~m}$ on a platform that extends, at that depth, in some places as much as $50 \mathrm{~km}$ offshore poses difficult challenges for underwater prehistoric research, more so in the open Atlantic
Portuguese coastal setting. However, in certain areas, there is steep bathymetry that brings potential areas of survey, testing and excavation much closer to the modern coast (Infantini et al. 2012). That is the case, for example, with the limestone cliff areas of the Setubal Peninsula or the western Algarve and the Nazaré and Portimão canyons. Not only is there a high potential for submerged caves, but also for underwater relict valleys and cliffs dating to the late Pleistocene. A perfect example is that of the Armação de Pêra Bay, where an MIS 3 barrier and cliff was found at a depth below sea level of some $20 \mathrm{~m}$ (Infantini 2012; Infantini et al. 2012). Directly to the north and on the top of the cliff, there is a large submerged platform. Bathymetric analysis shows a palaeolandscape that includes a barrier or coastal lagoon and dune field (Fig. 14.6), slowly modified and submerged during the Late Upper Palaeolithic and Early Holocene (Infantini 2012).

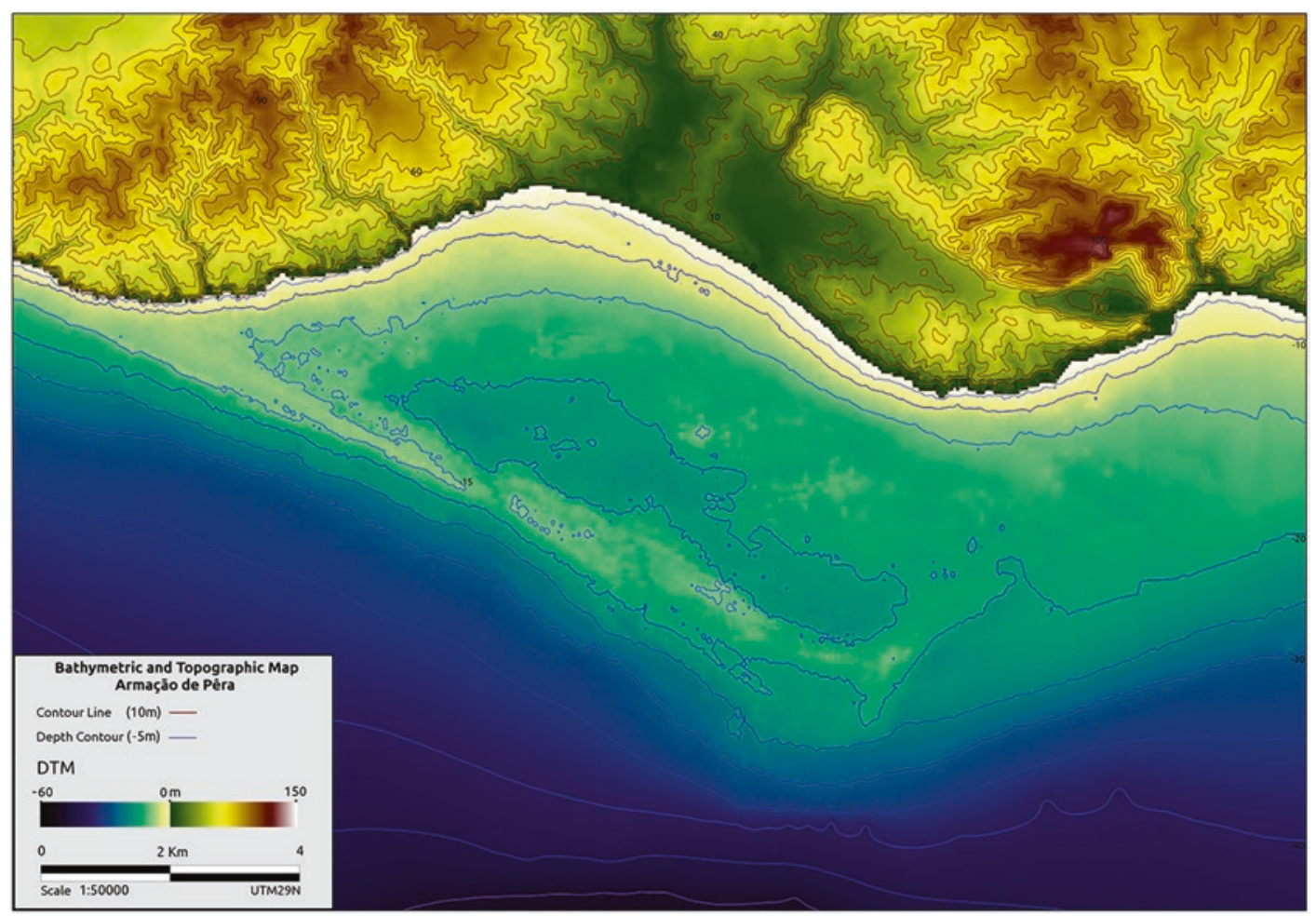

Fig. 14.6 A drowned Stone Age landscape some $20 \mathrm{~m}$ below present-day average sea level in Armação de Pêra Bay. The c. 12-km-long reef, representing a former peninsula, may have protected traces of human settlement from the erosive powers of waves from the open sea, making the area an obvious candidate for future underwater reconnaissance. Image by Leandro Infantini 
In addition to these specific regions with a steep bathymetry, there are two main coastal regions, one extending from the Nazaré canyon to the Sado estuary and the other comprising the southern coast between Cape St. Vincent and the Mondego estuary (Moura et al. 2017). Sediment deposition is higher in these regions, providing potentially moderate to good conditions for underwater preservation. Relict beach sediments in both areas are common, probably dating to the Last Interglacial, where there is a high potential for finding Middle Palaeolithic occupations, both open-air and cave sites. This potential is present in the coastal limestone around the Tagus and Sado estuaries as well as on the Sagres coast (Fig. 14.7) where many underwater caves are known, including at least two with dry sections inside the caves.

Palaeolagoon and coastal lake and island barrier contexts known in the Óbidos region, between the Tagus and Sado north of Sines and in the Faro area, also have very high potential, following detailed and systematic coastal and underwater surveys, for finding prehistoric settlements, similar to those described above. In many cases, there are similar geomorphological settings to those of the large Tagus and Sado river basins, but there are much smaller basins such as the Mira, Odeceixe, Aljezur, Carrapateira and Portimão, among many others, that may provide particularly good areas for finding either underwater or intertidal archaeological sites.

Many other areas need to be scrutinized, topographically reconstructed, tested and, in specific cases, excavated. A multidisciplinary research program at the University of Algarve is now under development to study the prehistoric human occupation of coastal cave settings in southern Portugal.

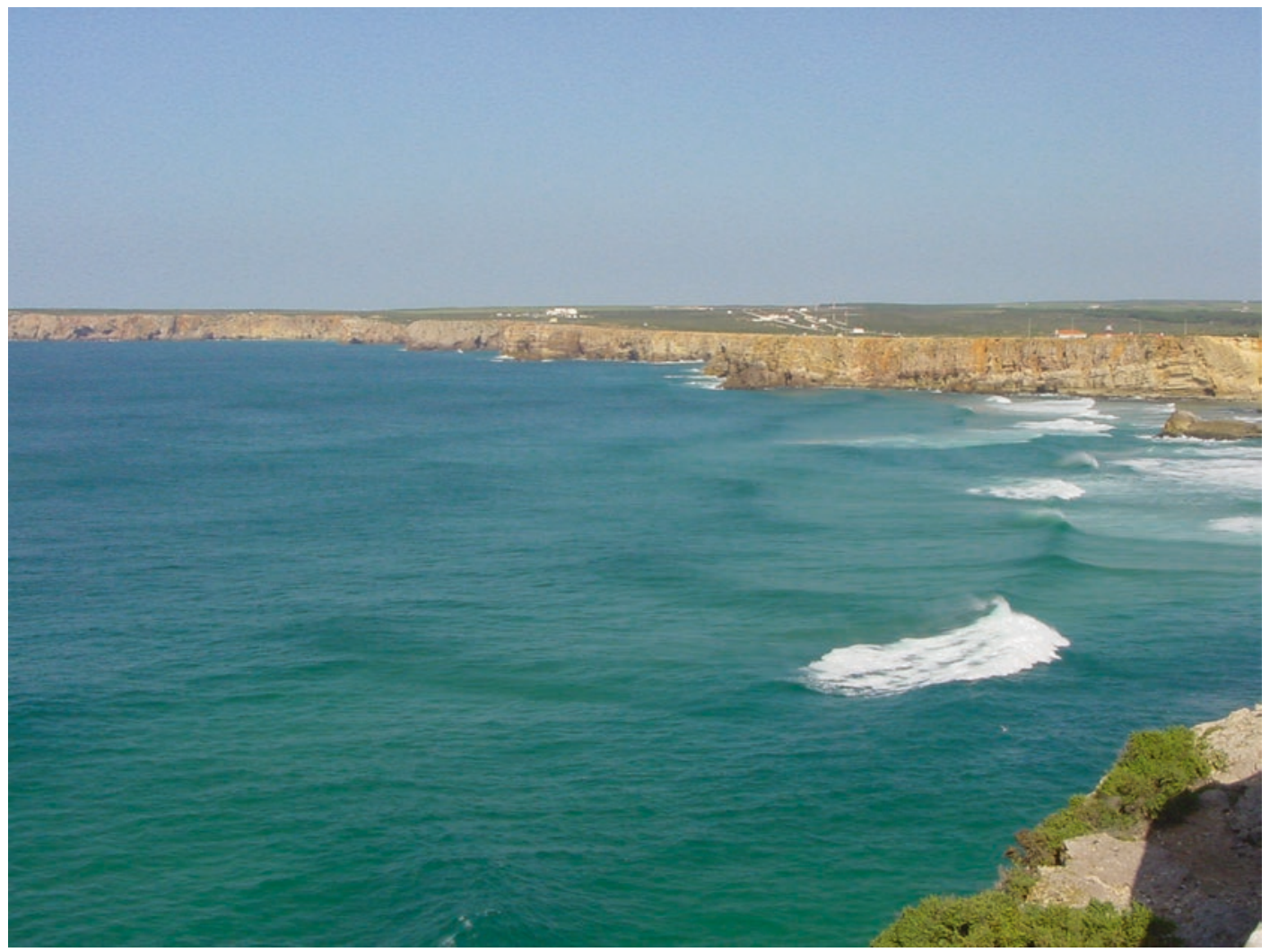

Fig. 14.7 General view of the southwestern coast of Sagres, with limestone cliffs 70-100-m high where caves are very common. Photo by Nuno Bicho 


\subsection{Management of the Underwater Cultural Heritage}

In the mid-1980s, the director of the National Museum of Archaeology, Francisco Alves, started to develop the field of underwater archaeology. His work eventually led to an autonomous department, the Centro Nacional de Arqueologia Náutica e Subaquática, in the Portuguese Archaeological Institute (Instituto Português de Arqueologia, IPA), the institution that supervised archaeological activity in Portugal from 1997 to 2006. IPA was replaced by IGESPAR (Instituto de Gestão do Património Arquitectónico e Arqueológico), and this in turn was replaced by the Direção Geral do Património Cultural (DGPC) in 2012. Within this governmental institution, there is a specific department that oversees the underwater archaeological heritage, the Divisão de Arqueologia Náutica e Subaquática. Presently. DGPC is the only institution in charge of the underwater archaeological heritage.

The Portuguese archaeological heritage is listed and available to the general public in an online database known initially as the Endovélico and very recently changed to the 'Portal do Arqueólogo'. Here, one can search for sites, absolute dates, site locations, periods as well as excavators (http://arqueologia.patrimoniocultural.pt/index.php?sid=sitios).

Acknowledgements We thank COST Action TD0902 SPLASHCOS for funding and particularly the Chair and Vice-Chair of the Action, Geoff Bailey and Dimitri Sakellariou. We also thank Fundação para a Ciência e Tecnologia for funding through the projects PTDC/EPHARQ/4998/2012 and PTDC/HAR-ARQ/27833/2017.

\section{References}

Abrantes F (1990) Increased upwelling off Portugal during the last deglaciation: diatom evidence. Mar Micropaleontol 17:285-310

Abrantes F (2000) 200000 yr diatom records from Atlantic upwelling sites reveal maximum productivity during LGM and a shift in phytoplankton community structure at 185000 yr. Earth Planet Sci Lett 176:7-16
Antunes M (2000a) The Pleistocene fauna from Gruta da Figueira Brava: a synthesis. Memórias da Academia das Ciências de Lisboa Classe de Ciências XXVIII:259-282

Antunes M (2000b) Gruta da Figueira Brava: Pleistocene marine mammals. Memórias da Academia das Ciências de Lisboa Classe de Ciências XXXVIII:245-258

Araújo A (2009) Hunter-gatherers adaptations during Pleistocene/Holocene transition in Portugal: data and explanatory models. In: McCartan S, Schulting R, Warren G, Woodman P (eds) Mesolithic horizons. Papers Presented at the Seventh International Conference on the Mesolithic in Europe Belfast, vol 2005. Oxbow, Oxford, pp 533-540

Araújo A (2012) Une histoire des premières communautés mésolithiques au Portugal. Unpublished PhD Thesis, Université de Paris 1, Panthéon, Sorbonne

Araújo A, Moreno-García M, Gabriel S (2014) O concheiro de Toledo no contexto do Mesolítico inicial do litoral da Estremadura. Rev Port Arqueol 17:5-34

Aubry T, Ribeiro J, Anglucci D (2005) Testemunhos da ocupação pelo Homem de Neanderthal: O sítio da Praia do Pedrogão. In: Carvalho S (ed) Habitantes e habitats: Pré e proto-História na Bacia do Lis. Câmara Municipal de Leiria, Leiria, pp 56-66

Bailey G (2004) World prehistory from the margins: the role of coastlines in human evolution. Journal of Interdisciplinary Studies in History and Archaeology $1: 39-50$

Bailey G, Milner N (2002) Coastal hunter-gatherers and social evolution: marginal or central? Before farming: The Archaeology of Old World Hunter-Gatherers 3(4): $1-15$

Benedetti M, Haws J, Funk D, Daniels M, Hespe P, Bicho N, Minckley T, Ellwood B, Forman S (2009) Late Pleistocene raised beaches of coastal Estremadura, Central Portugal. Quat Sci Rev 28:3437-3447

Bicho N (2004) As comunidades humanas de caçadoresrecolectores do Algarve Ocidental - perspectiva ecológica. In: Ferro AA, Tavares MJ, Cardoso J (eds) Evolução Geohistórica do Litoral Português e fenómenos correlativos. Universidade Aberta, Lisbon, pp 359-396

Bicho N (2009) On the edge: early Holocene adaptations in Southwestern Iberia. J Anthropol Res 65(2):185-206

Bicho N (2015) Ecological niches of the Iberian Peninsula: a comparative analysis of European coastal adaptations. In: Sanz N (ed) Human origin sites and the World Heritage Convention in Eurasia. UNESCO World Heritage Papers, pp 108-126

Bicho N, Cardoso J (2010) Paleolithic occupations and lithic assemblages from Furninha Cave, Peniche (Portugal). Zephyrus 66:17-37

Bicho N, Haws J (2008) At the land's end: marine resources and the importance of fluctuations in the coast line in the prehistoric hunter-gatherer economy of Portugal. Quat Sci Rev 27:2166-2175

Bicho N, Haws J, Hockett B, Markova A, Belcher W (2003) Paleoecologia e ocupação humana da Lapa do 
Picareiro: resultados preliminares. Rev Port Arqueol 6(2):49-81

Bicho N, Umbelino C, Detry C, Pereira T (2010) The emergence of the Muge Mesolithic shell middens (central Portugal) and the $8200 \mathrm{cal}$ yr BP cold event. Journal of Island and Coastal Archaeology 5:86-104

Bicho N, Cascalheira J, Gonçalves C, Umbelino C, García Rivero D, André L (2017) Resilience, replacement and acculturation in the Mesolithic/Neolithic transition: the case of Muge, central Portugal. Quat Int 446:31-42

Binford L (1968) Post-Pleistocene adaptations. In: Binford S, Binford L (eds) New perspectives in archeology. Aldine, Chicago, pp 313-341

Carvalho A (2008) A neolitização do Portugal Meridional. Os exemplos do Maciço Calcário estremenho e do Algarve Ocidental. Universidade do Algarve, Faro

Delgado JFN (1884) La grotte de Furninha a Peniche. Congrès International d'Anthropologie et d'Archéologie Préhistoriques. In: Compte-Rendu de la neuvième Session à Lisbonne (1880). Typographie de l'Académie Royale des Sciences, Lisboa, pp 207-278

Dias JA, Boski T, Rodrigues A, Magalhães F (2000) Coast line evolution in Portugal since the Last Glacial Maximum until present - a synthesis. Mar Geol 170:177-186

Erlandson JM (2001) The archaeology of aquatic adaptations: paradigms for a new millennium. J Archaeol Res 9:287-350

Fiuza A (1983) Upwelling patterns off Portugal. In: Suess E, Thiede J (eds) Coastal upwelling: its sedimentary record. Plenum, New York, pp 85-98

Flannery KV (1969) Origins and ecological effects of early domestication in Iran and the Near East. In: Ucko PJ, Dimbleby GW (eds) The domestication and exploitation of plants and animals. Aldine, Chicago, pp 73-100

García-Amorena I, Gómez Manzaneque F, Rubiales J, Granja H, Soares de Carvalho G, Morla C (2007) The Late Quaternary coastal forests of western Iberia: a study of their macroremains. Palaeogeogr Palaeoclimatol Palaeoecol 254:448-461

Granja HM, Carvalho GS (1995) Sea-level changes during the Pleistocene-Holocene in the NW coastal zone of Portugal. Terra Nova 7:60-67

Granja HM, De Groot TAM, Costa AL (2008) Evidence for Pleistocene wet aeolian dune and interdune accumulation, S. Pedro da Maceda, north-west Portugal. Sedimentology 55:1203-1226

Haws J, Funk CL, Benedetti M, Bicho N, Daniels M, Minkley T, Denniston R, Jeraj M, Gibaja J, Hockett B (2011) Paleolithic seascapes along the west coast of Portugal. In: Bicho N, Haws J, Davis L (eds) Trekking the shore: changing coastlines and the antiquity of coastal settlement. Springer, New York, pp 203-246

Infantini L (2012) Paisagem pré-histórica submersa da Baía de Armação de Pêra. Unpublished MA thesis, Universidade do Algarve, Faro
Infantini L, Moura D, Bicho N (2012) Utilização de ferramenta SIG para o estudo da morfologia submersa da Baía de Armação de Pêra (Algarve). In: Campar A, Bettencourt A, Moura D, Monteiro-Rodrigues S, Caetano-Alves M (eds) Environmental change and human interaction along the Western Atlantic edge. Associaçao Portuguesa para o Estudo do Quaternario, Coimbra, pp 227-242

Lambeck K, Rouby H, Purcell A, Sun Y, Sambridge M (2014) Sea level and global ice volumes from the Last Glacial Maximum to the Holocene. Proc Natl Acad Sci 111(43):15296-15303

Loureiro S, Newton A, Icely J (2005) Microplankton composition, production and upwelling dynamics in Sagres (SW Portugal) during the summer of 2001. Sci Mar 69:323-341

Minckley T, Haws J, Benedetti M, Brewer S, Forman S (2015) Last interglacial vegetation and climate history from the Portuguese coast. J Quat Sci 30:59-69

Moura D, Gomes A, Horta J (2017) The Iberian Atlantic margin. In: Flemming NC, Harff J, Moura D, Burgess A, Bailey GN (eds) Submerged landscapes of the European continental shelf: quaternary paleoenvironments. Wiley, Chichester, pp 281-300

Peyroteo Stjerna R (2016) On death in the Mesolithic, or the mortuary practices of the last hunter-gatherers of the south-western Iberian Peninsula, 7th-6th millennium BCE. Uppsala University, Occasional Papers in Archaeology 60, Uppsala

Rocha L (2003) Intervenções de emergência realizados pela extensão de Silves do Instituto Português de Arqueologia. Xelb 4:161-174

Rocha L, Barros P (1999/2000) Escavações de emergência no povoado da Praia do Forte Novo; Quarteira (Loulé). Al'-ulya 7:19-25

Sousa AC (ed) (2004) O núcleo C do concheiro de S. Julião (Carvoeira, Mafra): a escavação de emergência de 1999. Câmara Municipal, Cadernos de Arqueologia de Mafra 2, Mafra

Sousa AC, Soares AM (2016) Continuity or discontinuity? Aquatic exploitation in the Portuguese Estremadura during the Atlantic period: São Julião and Magoito shell middens as case studies. In: Dupont C, Marchand $\mathrm{G}$ (eds) Archéologie des chasseurs-cueilleurs maritimes. De la fonction des habitats à l'organisation de l'espace littoral. Actes de la Séance de la Societé Préhistorique Française, Rennes 10-11 Avril, vol 2014, pp 191-212

Sousa AC, Miranda M, Soares AM (2016) O Concheiro de São Julião (Carvoeira, Mafra): as intervenções de 2007 e 2014, novos dados e novas leituras. Rev Port Arqueol 19:11-26

Umbelino C (2006) Outros sabores do passado: as análises de oligoelementos e de isótopos estáveis na reconstituição da dieta das comunidades humanas do Mesolítico Final e do Neolítico Final-Calcolítico do território português. Unpublished PhD thesis, Universidade de Coimbra, Coimbra 
Valente M (2008) As últimas sociedades de caçadoresrecolectores no Centro e Sul de Portugal (10.000 6.000 anos BP): aproveitamento dos recursos animais. Unpublished PhD thesis, Universidade do Algarve, Faro
Von Grafenstein U, Erlenkeuser H, Müller J, Jouzel J, Johnsen S (1998) The cold event 8200 years ago documented in oxygen isotope records of precipitation in Europe and Greenland. Clim Dyn 14:73-81

Open Access This chapter is licensed under the terms of the Creative Commons Attribution 4.0 International License (http://creativecommons.org/licenses/by/4.0/), which permits use, sharing, adaptation, distribution and reproduction in any medium or format, as long as you give appropriate credit to the original author(s) and the source, provide a link to the Creative Commons licence and indicate if changes were made.

The images or other third party material in this chapter are included in the chapter's Creative Commons licence, unless indicated otherwise in a credit line to the material. If material is not included in the chapter's Creative Commons licence and your intended use is not permitted by statutory regulation or exceeds the permitted use, you will need to obtain permission directly from the copyright holder. 